\title{
Korelasi Jumlah Streptococcus mutans (S. mutans) dan Level Ekspresi Interlukin 8 (IL-8) pada Severe Early Childhood Caries
}

\author{
Muhammad Luthfi*, Retno Indrawati*, Ira Arundina*, dan Yoes Prijatna Dachlan** \\ *Departemen Biologi Oral, Fakultas Kedokteran Gigi, Universitas Airlangga, Surabaya, Jawa Timur, Indonesia \\ **Departemen Parasitologi, Fakultas Kedokteran, Universitas Airlangga, Surabaya, Jawa Timur, Indonesia \\ *JI Prof. Dr. Moestopo 47 Surabaya 60244, Indonesia; e-mail: m.luthfi7@yahoo.com
}

\begin{abstract}
ABSTRAK
Karies gigi pada anak usia dini merupakan masalah kesehatan yang sangat serius karena merupakan penyakit infeksi kronis yang menular. Dalam beberapa tahun terakhir pandangan tentang neutrofil telah berubah secara dramatis. Neutrofil tidak hanya berperan sebagai pembunuh mikroba melalui proses fagositosis, pelepasan reactive oxigen species (ROS) dan peptida antimikrobialnya tetapi neutrofil turut mengatur aktifasi respon imun. Interleukin-8 (IL8) berfungsi sebagai aktivator kuat dan kemoatraktan neutrofil oleh karena itu IL-8 merupakan mediator kunci dalam migrasi neutrofil ke lokasi peradangan dan infeksi. Untuk menganalisis hubungan dari jumlah $S$. mutans dan ekspresi IL-8 neutrofil saliva pada anak usia dini bebas karies dan severe early childhood caries (S-ECC). Perlakuan dilakukan pada dua kelompok yaitu isolasi dan menghitung jumlah $S$. mutans pada sampel saliva dan sampel hasil kumur dengan $\mathrm{NaCl} 1,5 \%$ yang diisolasi neutrofilnya kemudian dianalisis ekspresi IL-8 menggunakan flow cytometry dari 20 anak bebas karies dan 20 anak severe early childhood caries. Hasil nilai rata-rata diketahui bahwa jumlah S. mutans anak usia dini bebas karies lebih rendah $(513.500,00 \pm 185.565,28 \mathrm{CFU} / \mathrm{ml})$ dibandingkan dengan S-ECC $(977.000,00 \pm 222.500,15$ $\mathrm{CFU} / \mathrm{ml})$, sedangkan ekspresi IL-8 neutrofil saliva anak usia dini bebas karies lebih tinggi $(3,31 \pm 0,50)$ dibandingkan dengan S-ECC $(2,95+0,56)$. Penurunan ekspresi IL-8 neutrofil saliva kemungkinan sebagai penyebab meningkatnya jumlah S. mutans pada S-ECC.
\end{abstract}

Maj Ked Gi Ind. Desember 2015; 1(2): 142 - 148

Kata kunci: S-ECC, ekspresi IL-8, neutrofil saliva

ABSTRACT: Correlation of Streptococcus mutans (S. mutans) Level and Interleukin 8 (IL-8) Expressions of Salivary Neutrophils in Severe Early Childhood Caries. Early childhood caries is a very serious health problem because it is a chronic infectious disease that is contagious. Dental caries begins after the primary teeth grow and develop on the tooth surface very quickly and progressively. In recent years the views of neutrophils have changed dramatically. Neutrophils not only act as a microbe killer through phagocytosis, the release of reactive oxigen species (ROS) and its antimicrobial peptide, but neutrophil activation also helps regulate the immune response. To analyze the relationship between the amount S. mutans and IL-8 expression of salivary neutrophils in severe early Childhood caries. Two groups, namely Isolation of S. mutans were performed on saliva samples taken from 20 caries-free and 20 severe early childhood caries and samples Nacl 1,5\% mouthwash results of 20 caries-free and 20 severe early childhood caries salivary neutrophils that were analysis of IL-8 expression by flow cytometry. Based on the average value, it is known that S. mutans level in early Childhood caries-free is lower (513.500,00 $\pm 185.565,28 \mathrm{CFU} / \mathrm{ml}$ ) in comparison to the severe early Childhood caries $(977.000,00 \pm 222.500,15 \mathrm{CFU} / \mathrm{ml})$, but the expression of IL-8 neutrophil salivary neutrophils in early Childhood caries-free is higher $(3,31 \pm 0,50)$ in comparison to the severe early Childhood caries $(2,95 \pm 0,56)$. The increased S. mutans level is probably caused by the decrease in the expression of IL-8 salivary neutrophils in severe early childhood caries.

Maj Ked Gi Ind. Desember 2015; 1(2): 142 - 148

Keywords: severe early childhood caries, IL-8 expression, salivary neutrophils

\section{PENDAHULUAN}

Early chilhood caries merupakan masalah kesehatan yang sangat serius. The American Academy of Pediatric Dentistry (AAPD) pada tahun 2003 telah menyatakan keganasan penyakit ini karena merupakan penyakit infeksi kronis yang menular. ${ }^{1}$ Karies gigi dimulai setelah gigi sulung tumbuh dan berkembang pada permukaan gigi dengan sangat cepat dan progresif dengan manifestasi berupa nyeri, abses akut maupun kronis, demam, pembengkakan pada bibir sehingga nafsu makan menurun. $^{2}$

Severe early chilhood caries dengan decay exfolation filling teeth (def-t) $\geq 6$ merupakan bentuk yang sangat destruktif karena melibatkan beberapa gigi, termasuk gigi anterior rahang atas. ${ }^{3}$ 
Di Indonesia hasil penelitian Fitriani pada tahun 2007 di Semarang, menunjukkan bahwa sebesar 90,5\% di perkotaan dan $95,9 \%$ di pedesaan anak usia dini menderita karies gigi. ${ }^{4}$ Pada tahun 2006 di Surabaya hasil penelitian yang dilakukan Indawati menunjukkan bahwa $74 \%$ anak usia dini menderita karies gigi. ${ }^{5}$ Proses terjadinya karies adalah hasil dari pergeseran yang bertahap dan konsisten pada keseimbangan demineralisasi dan remineralisasi email gigi yang secara langsung dipengaruhi oleh $S$. mutans sebagai salah satu agen etiologi yang paling penting penyebab karies gigi. ${ }^{6}$

Dalam beberapa tahun terakhir pandangan neutrofil telah berubah secara dramatis, neutrofil yang merupakan komponen kunci dari garis pertahanan pertama terhadap mikroba. ${ }^{7}$ Neutrofil tidak hanya berperan sebagai pembunuhan terhadap mikroba dengan fagositosis, pelepasan reactive oxigen species (ROS) dan peptida antimikrobialnya tetapi neutrofil turut mengatur aktifasi respon imun, ${ }^{8}$ selain itu neutrofil terbukti telah menghasilkan berbagai sitokin, kemokin dan growth factor sehingga menjadi kontributor utama dalam produksi sitokin proinflamasi pada daerah infeksi. ${ }^{9}$

Interleukin-8 (IL-8) adalah anggota dari kemokin keluarga CXC yang berfungsi sebagai aktivator kuat dan kemoatraktan neutrofil oleh karena itu IL-8 merupakan mediator kunci dalam migrasi neutrofil ke lokasi peradangan dan infeksi. ${ }^{7}$ Setelah adanya stimulasi oleh gugus mikroba, G CSF atau GM - CSF, tumor necrosis factor - $\alpha$ (TNF - a) atau interferon Tipe I dan II dalam jaringan yang mengalami inflamasi, neutrofil yang teraktifasi secara fungsional menghasilkan IL-8. ${ }^{10}$

Fungsi penting dari neutrofil dalam membunuh mikroba patogen adalah fagositosis, yang secara signifikan lebih efektif karena adanya proses opsonisasi oleh antibody dan complement pada permukaan mikroba. Fagositosis terhadap mikroba dapat menyebabkan proses oxidative burst memproduksi reactive oxigen species yang disertai dengan degranulasi granula sitoplasma dalam phagosome yang mengandung mikroba yang banyak mengandung peptida antimikroba dan protease..$^{11}$

Berdasar latar belakang tersebut di atas, penelitian ingin mengidentifikasi faktor risiko dengan mengidentifikasi peran neutrofil saliva sebagai sebagai sel efektor innate immunity dalam mencegah terjadinya karies gigi.

\section{METODE PENELITIAN}

Penelitian telah mendapat persetujuan berdasarkan keterangan laik etik no 91/KKEPK.FKG/ VII/2013 dari Komite Kelaikan Etik Penelitian Kesehatan Fakultas Kedokteran Gigi Universitas Airlangga. Sampel yang diperoleh dari anak TK di wilayah Surabaya dilakukan pemeriksaan karies gigi terlebih dahulu dengan mengukur indeks def-t nya, dan setelah itu subjek yang telah dilakukan pemeriksaan dibagi menjadi dua kelompok, yaitu: kelompok bebas karies dan kelompok S-ECC dengan def-t lebih dari 6 . Semua subjek pada saat pengambilan sampel berusia antara 4 sampai dengan 6 tahun. Sebelum dilakukan pengambilan sampel pada subjek penelitian, dilakukan pembagian lembar kuesioner dan menandatangani lembar inform consent oleh orang tua masing-masing.

Sampel diambil dari saliva untuk penentuan level S. mutans dan dari hasil kumur $\mathrm{NaCl}$ $1,5 \%$ untuk penentuan ekspresi CD66b-IL-8 pada permukaan neutrofil saliva. Pengambilan sampel dilakukan oleh peneliti dan tenaga terlatih menggunakan standar protokol. Subjek tidak boleh makan, minum, mengunyah permen karet, atau menggosok gigi selama 60 menit sebelum pengambilan sampel. Setelah terkumpul sampel dibekukan pada suhu $-80^{\circ} \mathrm{C}$ untuk analisis. ${ }^{12}$

\section{Isolasi Penghitungan Koloni S. mutans dari Saliva}

Isolasi S. mutans dilakukan dari sampel saliva yang diambil dari anak prasekolah baik yang teridentifikasi sebagai karies berat maupun bebas karies dilakukan dengan cara sebagai berikut: Sampel saliva yang telah diperoleh diencerkan pada media Brain Heart Infusion Broth (BHI-B), kemudian diinkubasi selama 24 jam dan selanjutnya sampel ditanam pada media Triptone Yeast Cystein (TYC) agar koloni yang diduga $S$. mutans disubkultur untuk dilakukan uji biokimia menggunakan fermentasi manitol, rafinosa, sorbitol, salicin, esculin dan arginin. Isolat diidentifikasi sebagai $S$. mutans apabila positif untuk fermentasi gula-gula dan 
negatif untuk arginin, selanjutnya dikonfirmasi oleh pewarnaan Gram dan uji katalase. Isolat S. mutans pada pewarnaan Gram menunjukkan Gram positif dan dengan uji katalase menunjukkan katalase negatif inilah yang kemudian dilakukan penghitungan pada media TYC. ${ }^{12}$

Semua koloni S. mutans pada agar TYC berdasarkan morfologi dan uji yang telah dilakukan dihitung dengan menggunakan rumus: Jumlah koloni $\mathrm{x}$ faktor pengenceran $\times 50$ (volume $1 \mathrm{ml})=$ $\mathrm{CFU} / \mathrm{ml}$ dengan tingkat deteksi minimum adalah $1 \times 10^{3} \mathrm{CFU} / \mathrm{ml}$.

\section{Isolasi Neutrofil Saliva}

Neutrofil dalam saliva diperoleh dengan mengintruksikan subjek untuk berkumur dengan 10 ml larutan $\mathrm{NaCl}$ steril 1,5\% sambil dikumur-kumur, namun tidak ditelan selama 30 detik, kemudian diekspektorasi pada gelas steril. Prosedur ini diulang sebanyak 4 kali. Sampel selanjutnya disentrifugasi pada kecepatan $450 \mathrm{~g}$ selama 15 menit, pada suhu $4^{\circ} \mathrm{C}$. Pelet hasil sentrifugasi selanjutnya dicampur dengan $2 \mathrm{ml}$ medium RPMI, kemudian sampel di vortex lalu disaring secara berurutan dengan 20 dan $11 \mu \mathrm{m}$ nilon filter ${ }^{13}$ kemudian dilakukan neutrophils gate menggunakan flow cytometry.

\section{Pengukuran Ekspresi IL-8 pada Neutrofil Saliva}

Pengukuran profil sel neutrofil menggunakan antibody $\mathrm{CD} 66 \mathrm{~b}$ yang merupakan penanda aktivasi neutrofil. CD66b berada dalam membran granula primer yang terekspresi pada membran permukaan neutrofil dan meningkat karena adanya rangsangan pada sel neutrofil ${ }^{10}$ dengan tanda-tandanya tersebut dapat diukur dengan flow cytometry dengan metode yang telah dimodifikasi Bjornsson pada tahun $2005 .{ }^{14}$ Sampel yang digunakan adalah sampel hasil kumuran $\mathrm{NaCl} 1,5 \%$ yang telah diisolasi neutrofilnya. Suspensi sel neutrofil yang telah diisolasi kemudian dimasukkan ke dalam microtube yang telah diisi PBS sebanyak $500 \mu$ l. Suspensi sel kemudian disentrifugasi dengan kecepatan $2500 \mathrm{rpm}$, selama 5 menit pada suhu $4^{\circ} \mathrm{C}$. Pelet yang diperoleh kemudian diwarnai dengan antibodi ekstraseluler sebanyak $50 \mu \mathrm{l}$ (Biolegend antihuman $\alpha$-CD66bPE), dan Biolegend a-PI PE conjugated dengan perbandingan antibodi: PBS adalah 1:200. Sel yang telah ditambah antibodi kemudian disimpan pada suhu $4^{\circ} \mathrm{C}$ selama 30 menit, kemudian suspensi sel ditambah $1 \mathrm{ml}$ PBS dan disentrifugasi dengan kecepatan 2500 rpm, selama 5 menit pada suhu $4^{\circ} \mathrm{C}$. Pelet kemudian ditambah Biolegend Cytofix Cytoperm sebanyak $100 \mu \mathrm{l}$ dan dihomogenkan hingga tercampur rata. Inkubasi dlakukan dalam suhu $4^{\circ} \mathrm{C}$ dan keadaan gelap selama 20 menit. Setelah inkubasi, sel kemudian ditambah $1 \mathrm{~mL}$ Biolegend Washperm $1 X$ dan selanjutnya disentrifugasi pada kecepatan 2500 $\mathrm{rpm}$, selama 5 menit pada suhu $4^{\circ} \mathrm{C}$. Pelet yang diperoleh kemudian ditambah antibodi intraseluler, diantaranya BD antihuman IL-8 PerCP conjugated, selanjutnya suspensi sel dimasukkan ke dalam kuvet flow cytometer, ditambah PBS sebanyak 300 $\mu \mathrm{l}$, dan dipasang pada nozzle BD FACS Calibur untuk dilakukan running menggunakan mesin flow cytometer. Sampel dianalisis dengan flow cytometry (FACS Calibur flow cytometer, BD Bio Sciences, San Jose, CA).

Neutrophil gate diidentifikasi dengan menggunakan kerapatan dan ukuran dengan side angle light scatter lalu diteruskan dengan forward angle light scatter. Kompensasi ini dicapai dengan menggunakan FITC dan PE yang dilebel dengan antibodi yang bersifat individual.

Hasilnya dinyatakan sebagai mean fluorescence intensity (MFI). FACS Calibur dari Becton Dickinson dengan Program Cell Quest software yang digunakan untuk analisisnya.

\section{HASIL}

\section{Jumlah S. mutans Saliva pada S- ECC dan} Bebas Karies

Hasil penghitungan jumlah S. mutans dari kelompok severe early chilhood caries dan bebas karies dengan menggunakan colony counter terlihat pada Tabel 1. 
Tabel 1. Rerata dan simpangan baku jumlah $S$. mutans pada saliva yang dihitung dengan colony counter pada Severe Early Chilhood Caries (S-ECC) dan bebas karies (CFU/ml)

\begin{tabular}{lclll}
\hline Kelompok & $\mathbf{n}$ & Rata-rata \pm Simpangan Baku & $\mathbf{9 5 \%} \mathbf{C l}$ & Nilai $\mathbf{p}$ \\
\hline Free Karies & 20 & $513.500,00 \pm 185.565,28$ & $394.789,36-632.210,64$ & $<0,0001$ \\
S-ECC & 20 & $977.000,00 \pm 222.500,15$ & $834.661,22-1.119 .338,78$ & $(p<\alpha)$ \\
\hline
\end{tabular}

Hasil penghitungan jumlah $\quad$ S. mutans saliva dari media Tryptone Yeast Cystein Agar menggunakan colony counter yang dilakukan uji normalitas dan homogenitas, setelah menunjukkan data berdistribusi normal dan homogen kemudian dilanjutkan dengan uji beda menggunakan uji-t 2 sampel bebas yang menunjukkan nilai signifikansi lebih kecil dari $\alpha$. Hal ini berarti terdapat perbedaan yang signifikan jumlah $S$. mutans diantara dua kelompok. Berdasarkan nilai rata-rata diketahui bahwa jumlah $S$. mutans pada anak bebas karies lebih rendah dibandingkan dengan anak dengan karies berat.
Hasil analisis menggunakan flow cytometry neutrofil saliva teraktifasi $\left(\mathrm{CD} 6 \mathrm{~b}^{+}\right)$yang mengekspresikan IL- $8^{+}$dilakukan uji normalitas dan homogenitas, setelah menunjukkan data berdistribusi normal dan homogen kemudian dilanjutkan dengan uji beda menggunakan uji-t 2 sampel bebas yang menunjukkan nilai signifikansi lebih kecil dari $\alpha$, hal ini berarti terdapat perbedaan yang signifikan ekspresi ${\mathrm{IL}-8^{+}}^{+}$diantara dua kelompok. Berdasarkan nilai rata-rata diketahui bahwa neutrofil saliva yang mengekspresikan IL$8^{+}$pada early chilhood bebas karies lebih tinggi dibandingkan pada S-ECC.

Tabel 2 Rerata dan simpangan baku neutrofil saliva teraktifasi $\left(C D 66 \mathrm{~b}^{+}\right)$yang mengekspresikan IL-8 ${ }^{+}$ pada early chilhood bebas karies dan severe early chilhood caries (S-ECC) (\%)

\begin{tabular}{|c|c|c|c|c|}
\hline Kelompok & $\mathrm{n}$ & $\begin{array}{c}\text { Rata-rata } \pm \\
\text { Simpangan Baku }\end{array}$ & $95 \% \mathrm{Cl}$ & Nilai $p$ \\
\hline Free Karies & 20 & $3,31 \pm 0,50$ & $2,99-3,63$ & 0,040 \\
\hline S-ECC & 20 & $2,95 \pm 0,56$ & $2,59-3,31$ & $(p<\alpha$ \\
\hline
\end{tabular}
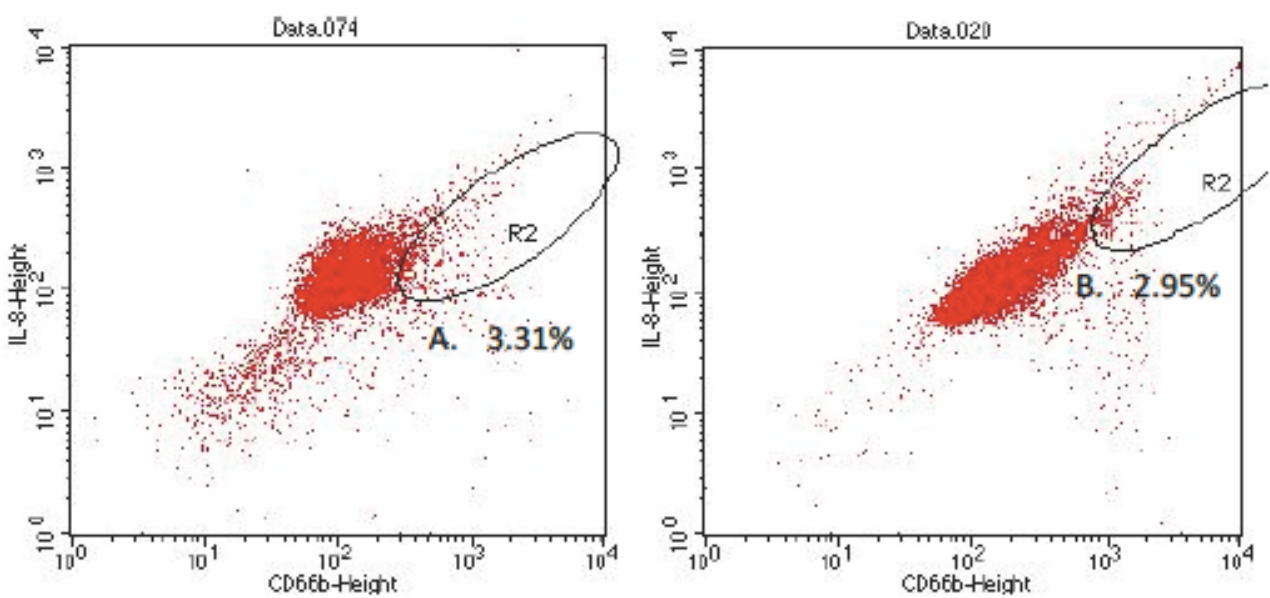

Gambar 1. Neutrofil saliva yang teraktifasi $\left(\mathrm{CD} 6 \mathrm{~b}^{+}\right)$yang mengekspresi IL-8 $8^{+}$yang dideteksi menggunakan flow cytometry pada early chilhood bebas karies (A) dan pada S-ECC (B) 


\section{PEMBAHASAN}

Early chilhood caries merupakan penyakit multifaktorial yang terjadi akibat serangkaian interaksi antara host yang rentan, bakteri kariogenik, diet kariogenik dan perilaku. Karies gigi bukan disebabkan bakteri eksogen, melainkan akibat dari penyimpangan ekologi sehingga bakteri komensal rongga mulut menjadi patogen setelah terjadi gangguan imunologi dan homeostasis tubuh yang kemudian berkembang menjadi karies gigi, adapun peran penting dalam homeostasis rongga mulut dan pencegahan karies gigi bergantung pada komponen immune yang ada di dalam saliva. ${ }^{15}$ Streptococcus mutans memainkan peran integral etiologi terjadinya early chilhood caries yang merupakan penyakit infeksi yang menular, ${ }^{11}$ sehingga $S$. mutans dianggap merupakan prediktor penting sebagai bakteri kariogenik karena bersifat acidogenic (mampu menghasilkan asam) dan aciduric (mampu bertahan dalam lingkungan asam. ${ }^{16}$

Dalam saliva, neutrofil merupakan garis pertahanan pertama yang paling menonjol dari immune cells untuk pertahanan terhadap mikroba patogen. Pentingnya neutrofil dalam host immune system pada penderita neutropenia atau cacat pada fungsi neutrofil yang menyebabkan kecenderungan untuk terjadinya infeksi yang serius. Proses perekrutan neutrofil, transmigrasi, fagositosis, dan aktivasi sangat terkoordinasi untuk mencegah atau menghilangkan infeksi pada manusia. Pada daerah infeksi, neutrofil mengikat dan menelan mikroba melalui suatu proses yang dikenal sebagai fagositosis.

Neutrofil mengenali permukaan-terikat atau molekul bebas disekresikan bakteri, termasuk peptidoglikan, lipoprotein, asam lipoteikoat (LTA), lipopolisakarida (LPS), DNA yang mengandung CpG, dan flagellin. Molekul patogen ini dikenal sebagai pathogen associated moleculer pattern (PAMPs,) berinteraksi langsung dengan sejumlah PRRs yang diekspresikan pada permukaan sel, termasuk toll like receptor (TLRs). ${ }^{17}$ Streptococcus mutans sebagai agen etiologi utama early chilhood caries karena mempunyai beberapa mekanisme untuk berkolonisasi pada permukaan gigi dan di bawah kondisi tertentu untuk menjadi spesies kariogenik yang secara signifikan paling tinggi dalam lingkungan biofilm rongga mulut, sehingga menunjukkan adanya hubungan sebab akibat antara karies gigi dengan tingginya jumlah S.mutans, beberapa penelitian menunjukkan bahwa perkembangan karies gigi didahului oleh peningkatan kolonisasi dari S. mutans, sedangkan peneliti lain mengatakan bahwa tingginya $S$. mutans pada saliva merupakan suatu indikasi pada peningkatan karies gigi. ${ }^{15}$

Interleukin-8 (IL-8) adalah anggota dari kemokin keluarga CXC yang berfungsi sebagai aktivator kuat dan kemoatraktan neutrofil oleh karena itu IL-8 merupakan mediator kunci dalam migrasi neutrofil ke lokasi peradangan dan infeksi. ${ }^{7}$ Setelah adanya stimulasi oleh gugus mikroba, G-CSF atau GM - CSF, tumor necrosis factor - $\alpha$ (TNF- $\alpha$ ) atau interferon Tipe I dan II dalam jaringan yang mengalami inflamasi, neutrofil secara fungsional diaktifkan yang kemudian menghasilkan IL-8. ${ }^{18}$

Berdasarkan hasil penelitian (Tabel 2) hasil penelitian pada neutrofil saliva menunjukkan bahwa level ekspresi IL- $8^{+}$pada severe early chilhood caries lebih rendah dibandingkan dengan level ekspresi IL-8+ ${ }^{+}$pada early chilhood bebas karies dengan nilai rata-rata diketahui bahwa level ekspresi IL- $8^{+}$yang terdeteksi pada neutrofil saliva S-ECC lebih rendah $(2.95 \% \pm 0,56)$ berbeda secara signifikan dibandingkan dengan level ekspresi IL- $8^{+}$pada early chilhood bebas karies $(3.31 \% \pm 0,50)$.

Berdasarkan hasil penelitian tersebut di atas rendahnya level ekspresi IL- $8^{+}$pada S-ECC bila dibandingkan dengan early chilhood bebas karies kemungkinan disebabkan oleh karena neutrofil saliva pada severe early chilhood caries kurang sensitif teraktifasi dibandingkan pada early chilhood bebas karies. Hal ini berhubungan dengan penelitian yang mengatakan bahwa IL-8 mengungkapkan perbedaan variasi pada tingkat ekspresinya, IL-8 hampir tidak disekresikan pada sel yang tidak terinduksi, sedangkan produksinya dengan cepat disebabkan oleh karena adanya rangsangan sitokin proinflamasi seperti tumor necrosis faktor (TNF) atau IL $-1 .{ }^{19}$ Ekspresi IL-8 
yang secara signifikan pada pada neutrofil saliva S-ECC lebih rendah dbandingkan pada early chilhood bebas karies ini kemungkinan bisa menyebabkan kurang efektif dalam pembunuhan S. mutans karena aktifitas oksidase NADPH rendah, selain itu proses degranulasi juga kurang aktif sehingga proses pembunuhan dalam phagosome menjadi menurun sehingga proses karies gigi terus berlanjut. IL-8 yang merupakan sitokin proinflamasi yang mempunyai efek potensial, memiliki aktifitas sebagai kemoatraktan serta mampu mengaktifkan dan proses degranulasi pada neutrofil. IL-8 merupakan regulator penting pada aktivasi dan migrasi neutrofil. ${ }^{20}$

Rendahnya ekspresi IL-8 juga dipengaruhi oleh Nuclear Factor kappa B (NF-kB) dan Mitogen activated protein kinase (MAP kinase) pada neutrofil saliva, hal ini disebabkan karena NFkB memainkan peran sentral dalam mengatur transkripsi sitokin, molekul adhesi dan mediator lainnya yang terlibat dalam menanggapi respons dan MAP kinase memberikan kontribusi peraturan peristiwa inflamasi akut yang kompleks, seperti mitogenesis, diferensiasi, kelangsungan hidup, dan migrasi. ${ }^{21}$ Rendahnya marker ekspresi fagositosis dan degranulasi neutrofil saliva menyebabkan rendahnya granulasi neutrofil elastase sehingga menyebabkan penurunan transkripsi gen IL-8 melalui mekanisme MyD88/IRAK/TRAF6 diperkuat dengan hasil penelitian menunjukkan bahwa NF$\mathrm{kB}$ inhibitor, MAP kinase inhibitor secara signifikan menekan sintesis IL-8 yang terdapat pada neutrofil, hal ini mengindikasikan bahwa keterlibatan jalur NFkB dan MAP kinase juga dapat menyebabkan peningkatan produksi IL- 8 pada neutrofil setelah kontak atau diaktifkan oleh patogen. ${ }^{22}$

Jalur sinyal NF-kB memainkan peran penting dalam peradangan, imunitas, proliferasi sel, diferensiasi, dan kelangsungan hidup neutrofil serta sejumlah besar gen. dengan demikian deregulasi NF-kB dikaitkan dengan sejumlah besar penyakit. Untuk membuktikan bahwa deregulasi NF-kB dapat terjadi pada neutrofil saliva dapat menurunkan produksi IL-8 sebagai salah satu penyebab terjadinya severe early chilhood caries masih memerlukan penelitian lebih lanjut.

\section{KESIMPULAN}

Menurunnya ekspresi IL-8 pada neutrofil saliva mungkin menjadi salah satu penyebab meningkatnya jumlah $S$. mutans pada S-ECC.

\section{DAFTAR PUSTAKA}

1. American Academy of Pediatric Dentistry, Organizing Council. Definition of early chilhood caries (ECC). Pediatr Dent. 2003; 25: 9 .

2. Filstrups SL, Briskie D, Fonseca M, Lawrence L, Wandera A, Inglehart MR. ECC and quality of life: child and parent perspectives. Pediatr Dent. 2003; 25: 431-440.

3. Tinanoff $\mathrm{N}$, Reisine S. Update on early childhood caries since the Surgeon General's Report. Academic Pediatr. 2009; 9(6): 396403.

4. Fitriani. Faktor resiko karies gigi sulung anak (studi kasus anak TK Pangeran Diponegoro Semarang). Skripsi. Semarang: Universitas Diponegoro; 2007.

5. Indrawati R. Aktivitas enzim dextranase dan sebaran genotype Streptococcus mutans penderita karies dan bebas karies. Disertasi. Surabaya. Program Pascasarjana Universitas Airlangga; 2006.

6. Takahashi N, Horiuchi M, Yamada T. Effects of acidification on growth and glycolysis of streptococcus sanguis and streptococcus mutans. Oral Microbiol Immunol. 1997; 12(2): 72-6.

7. Elbim C, Katsikis PD, Estaquier J. Neutrophil apoptosis during viral infections. Open Virol J. 2009; 3:52-9.

8. Nathan. Neutrophils and immunity: challenges and opportunities. Nat Rev Immunol. 2006; 3:173-82.

9. Mantovani AMA, Cassatella C, Costantini, Jaillon $\mathrm{S}$. Neutrophils in the activation and regulation of innate and adaptive immunity. Nat Rev Immunol. 2011; 11: 519-531. 
10. Baggiolini M, Dewald B, Moser B. Human chemokines: An update. Annu Rev Immunol. 1997; 15: 675-705.

11. Kobayashi SD, Voyich JM, Burlak C, DeLeo FR. Neutrophils in the innate immune response. Arch Immunol Ther Exp. 2005; 53 : 505-517.

12. Phattarataratip E. The role of salivary antimicrobial peptides in shaping Streptococcus mutans ecology. Dissertation, University of lowa disease pathogenesis. Annu Rev Microbiol. 2010; 57:677-701.

13. Gasparoto TH, Vieira NA, Porto VC, Campanelli AP, Lara VS. Differences between salivary and blood neutrophils from elderly and young denture wearers. J Oral Rehabil. 2011; 38(1): 41-51.

14. Borjesson DL, Kobayashi SD, Whitney AR, Voyich JM, Argue CM, DeLeo FR. Insights into pathogen immune evasion mechanisms: Anaplasma phagocytophilum fails to induce an apoptosis differentiation program in human neutrophils. J Immunol. 2005; 174: 63646372.

15. Tanzer JM, Livingston J, Thompson AM. The microbiology of primary dental caries in humans. J Dental Edu. 2001; 65(10): 10281037.
16. Tinanoff N, Reisine S. Update on early childhood caries since the Surgeon General's Report. Academic Pediatr. 2009; 9(6): 396403.

17. Akira S, Takeda K. Toll-like receptor signalling. Nat Rev Immunol. 2004; 4: 499-511.

18. Sorensen $\mathrm{OE}$, Follin $\mathrm{P}$, Johnsen $\mathrm{AH}$, Calafat J, Tjabringa GS, Hiemstra PS, Borregaard N. Human cathelicidin, hCAP-18, is processed to the antimicrobial peptide LL-37 by extracellular cleavage with proteinase 3 . Blood. 2001; 4:421- 424.

19. Brasier AR, Jamaluddin $M$, Casola A, Duan W, Shen Q, Garofalo RP. J Biol Chem. 1998; 273, 3551-3561.

20. Juffrie $M$, van der Meer GM, Hack CE, Haasnoot K, Sutaryo, Meerman AJP, Thijs LG. Inflammatory mediators in dengue virus infection in children: interleukin-8 and its relationship to neutrophil degranulation. Infect Immun. 2000; 68:702-707.

21. Kim JS, Kim JM, Jung HC, Song IS. Expression of cyclooxygenase-2 in human neutrophils activated by Helicobacter pylori water-soluble proteins. Dig Dis Sci. 2001; 46: 2277-2284.

22. Ryun JS, Kang JH, Jung SY, Shin MH, Kim JM, Park H, Min DY. Production of interleukin-8 by human neutrophils stimulated with trichomonas vaginalis. Infect Immun. 2004; 72 (3): 1326-1332. 